\title{
NYELVTANULÁS KARIKATÚRÁKKAL ÉS KÉPREGÉNYEKKEL
}

\author{
Szerző: \\ Szalay Kristóf \\ Mozgásjavító Általános Iskola, \\ Szakközépiskola, Egymi és Diákotthon
}

Lektorok:

Vargáné Nagy Anikó

Debreceni Egyetem

Mező Ferenc

Debreceni Egyetem

Molnár Balázs

Debreceni Egyetem

Nemes Magdolna

Debreceni Egyetem
Szerző e-mail címe: szalay.kristof@gmail.com

Szalay K. (2016): Nyelvtanulás karikatúrákkal és képregényekkel. Különleges Bánásmód, II. évf., 2016/1. szám, 73-85. DOI 10.18458/KB.2016.1.73

\begin{abstract}
Absztrakt
A képregények és a karikatúrák alkalmazása hatékony eszköze lehet a tehetséggondozásnak az idegen nyelvi területen. Jelen tanulmány bemutatja, hogy: a) hogyan használhatjuk a képregények és karikatúrák lehetöségeit a tanulók kreativitásának fejlesztésére az idegen nyelvi tantárgyak kereteiben; b) milyen kooperatív módszereket alkalmazhatunk a rajzok segítségével; c) hogyan motiválhatjuk tanulóinkat a nyelvtanulásra?
\end{abstract}

Kulcsszavak: karikatúra, képregény, tehetséggondozás, nyelv

Diszciplina: pedagógia

\begin{abstract}
LEARNING FOREIGN LANGUAGE WITH CARICATURES AND COMICS

Applying comics and cartoons can be an effective method of talent development in the area of learning foreign languages. The present study shows: a) how we can use the possibilities of comics and cartoons to develop the creativity of students in the frame of foreign language lessons; b) what cooperative methods we can apply with help of the drawings; c) how we can motivate our students to learn languages.
\end{abstract}

Keywords: caricature, comics, talent development, language

Discipline: pedagogy

\section{Miért éppen a képregény?}

A következő oldalakon a karikatúrákra, képregényekre épülö konkrét gyakorlatokat, feladattípusokat mutatunk be, hogy a most felnövő generáció igényeihez újszerü és egyedi módszereket vagy eszközöket ajánljunk, amelyek ismét motiválhatják a diákokat a nyelvtanulásra. 
Ha valaki megkérdezné, miért pont a képregényt válasszuk a nyelvtanítást elősegítő, elsődleges közvetítő médiumnak, a következő érveket lehetne felsorolni:

- motiválja a diákokat (megj.: a tavalyi évben, a központi magyar felvételin a diákoknak kedvenc hősükről kellett írniuk. A magyar szakos kolléganőm megmutatta az iskolánkban felvételiző diákok munkáit. A 14 éves gyerekek túlnyomó része képregény és rajzfilmfigurát jelölt meg kedvenc hösként);

- egy adott ország kultúrája is megjelenik benne (például az amerikai képregényekben a szuperhősök mindig a társadalom elvárásait és véleményét képviselik a politikai és gazdasági eseményekben);

- a beszélt nyelvre épít, beszélt nyelvi kifejezések találhatók benne, azaz a leghasználhatóbb szókincs!

- vizualitása segíti a befogadást, könnyíti a szavak megjegyzését a két agyféltekés rögzítésnek köszönhetően (míg bal agyféltekénk a szavak, úgy jobb agyféltekénk a képek megjegyzéséröl gondoskodik).

- logikai készséget is fejleszt - a karikatúráknál (és sokszor a képtörténeteknél is) rá kell jönni a poénra;

- kapu lehet az olvasáshoz, mert a mai gyerekek kezdenek leszokni az olvasásról. Sokan azt gondolják, hogy ezért a képregény a felelős. Ellenkezőleg, a képregény sok esetben megszeretteti az olvasást. A képregényben megvan a potenciál, hogy a gyerekek utána novellákat, regényeket is szívesen elolvassanak;

- számos kreativitást fejlesztő gyakorlat épülhet rá;

- a képregénnyel a beszéd és az íráskészség egyaránt remekül fejleszthető, hiszen a képregények eljátszhatóak, mivel a legtöbb képregényben a dialógus dominál. Továbbá a rengeteg képleírás és történetmesélés mind-mind a beszédkészséget segíti. Ami az íráskészséget illeti: a diákok a már megtanult képregény szövegét írásban visszaadják, ezzel a helyesírást is gyakorolják.

- rövidség, gyorsaság (egy mai gyerek átlagosan 6-7 percig képes koncentráltan figyelni, ezután új ingerekre van szüksége a figyelem fenntartásához. A képregény rövid és gyorsan végigolvasható, az újabb és újabb képek és cselekmény képes hosszabb ideig lekötni a gyereket.)

Összességében a verbális információ átadás lehetősége mellett/helyett a képregények vizuális jellege jól illeszkedik a mai tanulók információfeldolgozó sajátosságaihoz: például a kreatív tanulás IPOO-modellje (Mező, 2011) aspektusából a képregény egyaránt hasznos lehet a tanulás input, process és output fázisában. Mint Gyarmathy (2011) írja, digitális korunk jól azonosítható neurológiai változást okozott az új generációkban, mivel az új, digitális kultúra egyre inkább a jobb agyféltekére épít, míg a hagyományos írásbeliség eddig a bal agyféltekét erösítette. A képregényben lehetőség van az írásbeliség és képiség, a verbalitás és a vizualitás szintetizálására: a rajzolás a jobb, az pedig írás a bal félteke feladata. Míg az írás/olvasás egyfajta irányított, kontrollált, elemzett tevékenység, addig a rajzolást és a vizuális élmények befogadását sokkal inkább az érzés, a holisztikus, a térlátás, a vizualitás jellemzi. A problémát az jelenti, ha az iskola nem vesz tudomást a (nem politikai, hanem agyféltekei értelemben) jobbra tolódó világról, s az oktatás továbbra is erősen a bal agyféltekére épít.

\section{A karikatúráról röviden}

A karikatúra megítélése hazánkban a képregényhez hasonlóan alakult. Koczogh (1981) szerint a karikatúra olyan múvészi alkotás, melyet sokan nem tekintenek müvészetnek, igazi grafikának, és nem sorolnak az autonóm müvészet - rég elavult - kategóriáiba. Sokan napjainkban sem veszik tudomásul társadalom-formáló erejét, s nem tartják filozófiának - 
mert annak felkent papjai vannak -, s nem tartják morálnak, mert azt megint mások hivatottak őrizni. Ugyanakkor annak ellenére, hogy a karikatúra kimarad a müvészetből, tudományból, filozófiából, erkölcstanból, mégis él és hat és a közlés, a kommunikáció mindennapi eszköze, az igazság szószólója (Gyöngy, 2008).

A karikatúra helyét a komikum területén kell keresnünk (Kaposy, 2001). A karikatúra tulajdonképpen maga a csattanó, hiszen tömören, egyetlen rajz segítségével mutatja be egy esemény vagy történés kulcs-momentumát, ami rávilágít a szituáció megértésére. A karikatúra tehát maga a tetőpont, kiemeli a lényeget, ugyanakkor képes elgondolkodtatni, hiszen sokszor szavak nélkül operál: az olvasónak kell apró, elrejtett jelekből megfejteni a mondanivalót, és amikor a poén leesik, bekövetkezik az ismert drámai elem, a katarzis. A karikatúra a képregény egysége, a képtörténet összefoglalója: az adott kockából mi, olvasók következtetünk a történet előzményeire és sokszor továbbgondoljuk a képet, agyunkban tehát az egyetlen kép cselekménysorként, képregényként jelenik meg.

A karikatúra a képregénynél már jóval korábban jelen volt: a XVII. században elsősorban kritikai szerepet töltött be: a karikatúristák eszköze volt, akik egy-egy rajzzal próbáltak reagálni a társadalmi folyamatokra, rávilágítottak azok fonákságaira, bírálták az aktuális politika rendszert és ezzel az ,igazság szócsövévé” váltak, nem csak a szórakoztatás tehát a karikatúra elsődleges célja. Hanem, hogy rádöbbentsen bennünket az igazságra. Ehhez a karikatúrának mindenféle sallangoktól mentesnek, kifejezőnek kell lennie. Igazi kihívás egy karikaturista számára a szöveg nélküli karikatúra, hiszen ott nincs ott a mankó, azaz a szöveg, ami sokszor egyértelmüvé teszi a rajzot. Ráadásul a szöveg nélküli karikatúrák nemzetköziek: a világon mindenkihez szólnak és ezért jelenleg az internet korában még gyorsabban terjedhetnek szöveges társainál.

A karikatúra hazai veteránja, az idén 95 éves Kaján Tibor így nyilatkozott a karikatúráról: „Egyesek szememre lobbantották, hogy rajzaim nem eléggé közérthetőek. Ezt kötve hiszem. Inkább arról van szó, hogy nem lehet mindegyiküket azonnal, fáradság nélkül megérteni. De hát miért baj, ha az érdeklődő egy intellektuális terméket tíz másodpercnél tovább tart a kezében? Én az ilyesmit inkább előnynek érzem. Igenis, fáradjon a néző, az olvasó szánjon rá némi »gondolkodási« időt, amíg a tetszetős ötlet mögé hatolva eljut a tartalom mélyebb rétegéig."

Ötletek a karikatúrákkal kapcsolatos feladatokhoz:

1. „Brainstorming”a karikatúrával kapcsolatban. Egy új téma bevezetéséhez a tanár kikeres a témához illő egy vagy több karikatúrát és a rajzos kép megbeszélése során összegyüjtik a legfontosabb szavakat és kifejezéseket, amelyek a diákoknak a képröl eszébe jutnak. Osztály-verseny is szervezhető: 2-3 fős csoportok kapják meg ugyanazt a karikatúrát és egy meghatározott idő alatt kell minél több szót felírniuk. A rajzok humoros mivolta már önmagában motiválni fogja a diákot és megteremti a feszültségmentes „laza” légkört a tanóra első perceiben. Fontos, hogy a képleírás csak az utolsó mozzanata legyen a gyakorlatnak és hagyjunk teret az asszociációs gondolkodásnak, a gondolkodás olyan formájának, amely a problémamegoldás alapját képezi és fejleszti a kreatív viselkedéshez szükséges képességeket. A rajzokat célszerü legalább A4-es vagy A3-as méretben kinagyítani és az óra elején a táblára ragasztani. Legjobb, ha színes másolatot készítünk (amennyiben az eredeti rajz is színes), de a projektoros kivetítés is nagyon jó megoldás.

2. Címadás. Felragasztunk a táblára 4-5 rajzot, a diákok pedig megpróbálnak címet találni nekik (1. ábra). Itt nincs rossz megoldás, a tanár szinte minden címötletet elfogad és a képek alá írja azokat. Vagy még jobb, ha a diákok maguk mennek a táblához és írják oda ötleteiket. A feladat végén pedig együtt végignézzük a megoldásokat és a legjobbakat egy nyilvánvaló öszinte nevetés kíséri majd. A végén természetesen elárulhatjuk a rajz eredeti címét is, de 
elképzelhető, hogy már az is szerepel a táblán, mint ötlet, sőt, az sem kizárt, hogy az eredetinél is sokkal szellemesebb megoldások születtek. Fontos, hogy ez az eredeti megoldás csak úgy „mellékesen”, érdekességképpen legyen tálalva és mindenképpen erősítsük a diákban pozitív visszajelzések formájában, hogy az általa kitalált cím egyenrangú vagy akár szellemesebb az eredetinél is.

1. ábra: példa a „Mi lehet a címe a karikatúrának?” típusú feladatra. Forrás: Szalay (2014, 81. o.) Deutch mit Comics 2. címü müvéböl

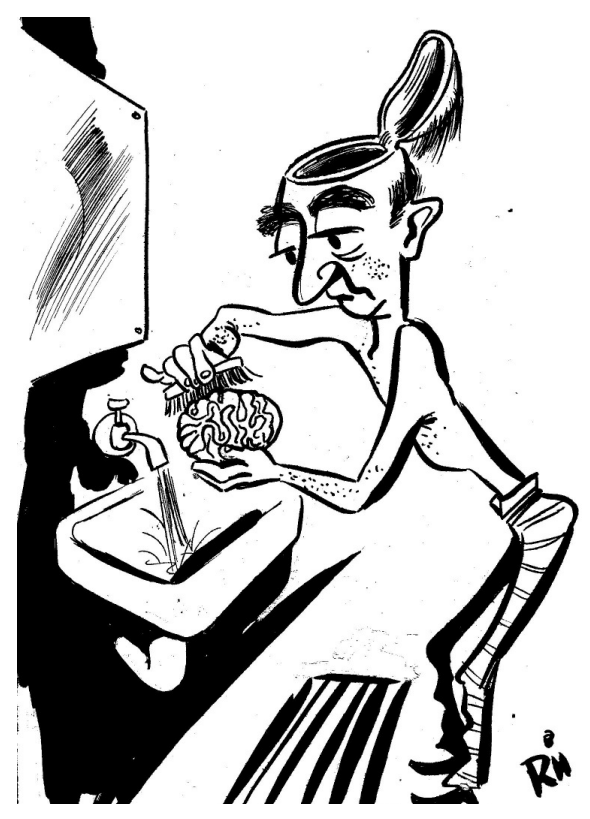

3. Címkeresés: itt a tanulók több megadott címböl keresik ki a nekik legjobban tetszőt, illetve próbálnak rájönni, hogy vajon melyik lehet a kép eredeti címe. Ennek a játéknak egy másik verziója, hogy például öt rajzot és öt címet összekeverünk, a diákok pedig megpróbálják a címeket a hozzá tartozó rajzhoz párosítani.

4. Kép alkotása címhez: adhatunk mi is akár egy címet vagy egy rövid szöveget a diákoknak, akik aztán rajzot készítenek hozzá. Ezt az ötletet lehet még úgy variálni, hogy az óra témájához választunk ki 10 darab közmondást vagy szólásmondást. A diákok akár házi feladatnak is kaphatják, hogy otthon egy általuk választott közmondáshoz készítenek egy vicces rajzot, a következő órát pedig kezdhetjük azzal, hogy az elkészült rajzokból kiállítást tartunk a teremben, a tanulók pedig megtippelik, melyik közmondás szolgált a rajz alapjául.

5. Kép-szöveg párosítás: a képekhez tartozó szövegeket keverjük össze, és a diákok feladata lehet a helyes szöveg kép alá helyezése. Hogy nehezebb legyen: válasszunk ki öt képet és adjunk 10 mondatot a diákok kezébe, amiből az öt megfelelőt kell a rajzokhoz ragasztani.

6. Képaláírás alkotás: írjanak a diákok maguk egy-két mondatos szöveget a képek alá. Sok karikatúra csak akkor válik igazán humorossá, ha az alatta lévő szöveget ismerjük. A kihívás a diáknak tehát adott: olyan mondatot kell írnia, ami nemcsak illik az adott képi környezetbe, de szellemes is és magában hordozza a csattanót (2. ábra) 
2. ábra: példa az „Írjunk csattanós képaláírást, kommentárt a karikatúrához!” jellegü feladatra. Forrás: Szalay (2014, 88. o.) Deutch mit Comics 2. címü müvéből

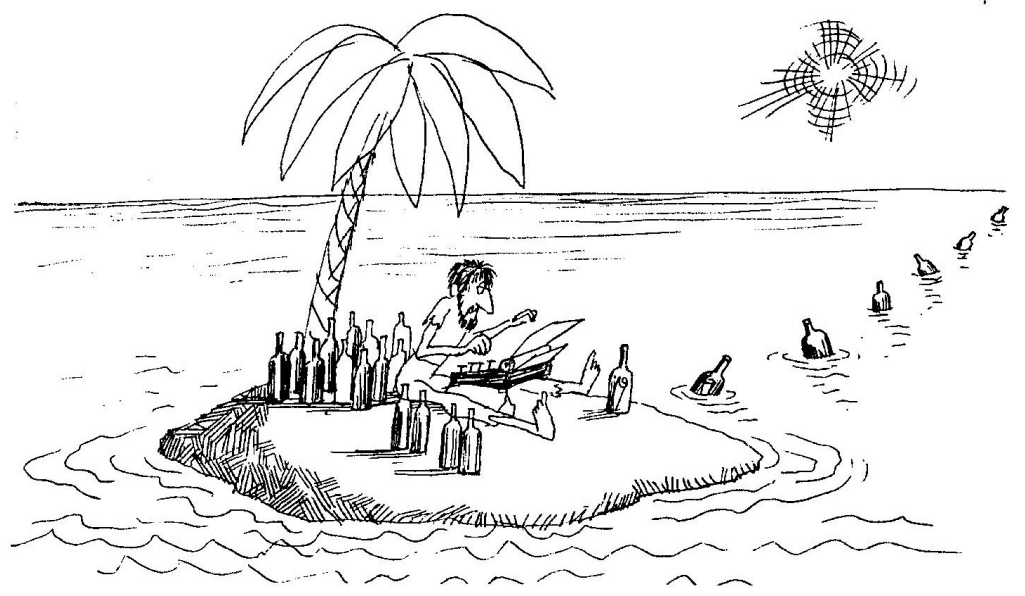

7. Képalkotás képleírás alapján. Kiválasztunk egy diákot és egy rajzot, a rajzot csak az a diák láthatja, aki megkapja. A diák kijön a táblához és elmeséli mit lát a rajzon, a többiek pedig lerajzolják, amit hallanak (és amennyit értenek az idegen nyelven történő képleírásból). A végén megnézzük, kinek a rajza áll legközelebb az eredetihez, és az is kiderül, hogy a beszélő mennyire tudta hüen visszaadni a rajzon látottakat (3. ábra).

3. ábra: példa a „képalkotás képleírás” típusú feladatra. Forrás: Szalay (2013, 43. o.) Deutch mit Comics1. címü müvéböl

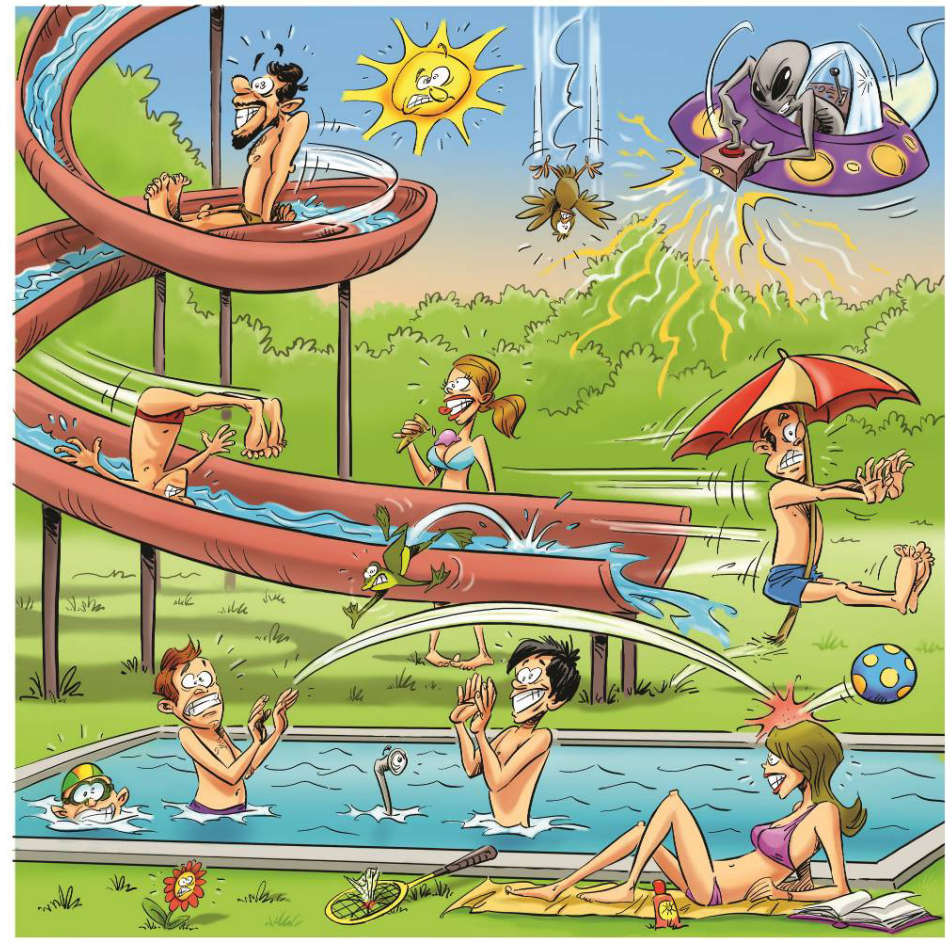


8. Képtorpedó. Kiválasztunk egy nagy, mozgalmas és részletekben gazdag képet - például olyat, mint a Deutsch mit Comics 1-2. könyvek (Szalay, 2013, 2014) leckéinek bevezető képei -, amit legalább A3-as méretben a táblára ragasztanunk vagy kivetítünk. A képet felosztjuk 9 egyenlő négyzetre (A1-től C3-ig - lásd: 4. ábra) és ezekről a négyzetekről beszélgethetünk külön-külön. A „torpedó” játékhoz hasonlóan a legkülönfélébb kérdéseket tehetjük fel: „Mit látunk az A1-en? Mi történik a B2-ben?” stb.. Miután a képet teljesen „kiveséztük”, a feladatot félretehetjük, majd következő órán egy memóriajáték keretében újra elővehetjük (lásd: 9. feladat a karikatúrákkal kapcsolatban).

\section{4. ábra: Képtorpedó. Forrás: Szalay (2014, 46. o.) Deutch mit Comics 2. címü müvéböl}

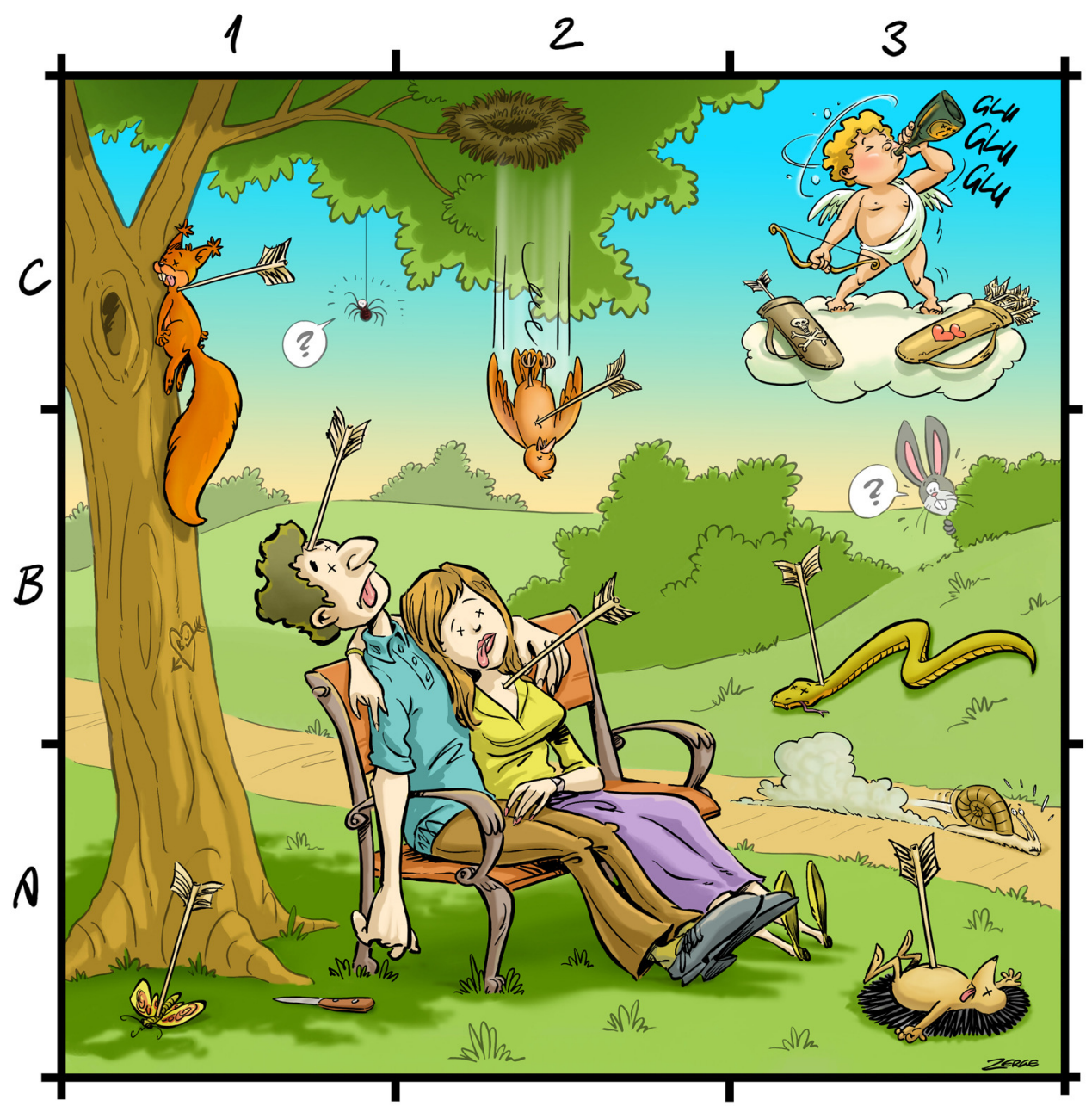

9. Memóriajáték. Felrajzolunk a táblára egy kilenc négyzetből álló üres rácsot és megkérjük a gyerekeket, hogy emlékezetből meséljék el, mi volt látható a korábban bemutatott „képtorpedóban” (vö.: 4. ábra) az adott négyzetben. A beszélgetés során szép lassan felrajzoljuk közösen az egyes képelemeket, majd a legvégén a tanár előveszi az eredeti képet és megnézhetjük, hogy mennyire volt jó a memóriánk. 
10. Rajzkiegészités képtorpedó alapján. A gyerekek párokba rendeződnek és egymással szemben ülnek, majd mindkettőjüknek kiosztjuk a „képtorpedó” rajzot (4. ábra), de úgy, hogy az egyikük rajzából korábban kiradíroztunk részeket. A teljes rajz birtokosa elmeséli a hiányos rajz birtokosának a hiányzó elemeket, ő pedig berajzolja azokat. A végén ellenőrzik megoldásukat.

11. Képtorpedó részletből következtetés az egész képre. A tanár kiválasztja a „képtorpedó” (4. ábra) egy képrészletét, amit a táblára ragaszt. A diákok a részletből arra próbálnak rájönni, hogy mi lehet az egész képen, illetve kitalálnak olyan alternatívákat, ami lehetne akár a kép folytatása is. Ugyanez a feladat kicsit másképp: a képen szereplő egyik figura teljes alakját vágjuk ki és ragasztjuk a táblára, a diákok pedig ötleteket adnak, hogy vajon milyen környezetből „emeltük ki” az adott rajzfigurát. Ezt a feladatot is lehet tovább variálni: kiválasztunk két figurát egy több figurát ábrázoló rajzról és a tanulók megpróbálják összekapcsolni a két személyt: olyan szituációkat vagy helyeket találnak ki, ahol a két személy egymásra hat. Még érdekesebb a játék, ha két olyan figurát választunk, akik, nem egy képen láthatóak, tehát nem illenek semmilyen ponton össze. És persze ezt a játékot játszhatjuk bármilyen más képrészlettel: tárgyakkal, állatokkal, a tanulóknak tehát nemcsak ember-ember, hanem ember-állat, ember-tárgy vagy tárgy-állat között is kapcsolatot kell keresniük.

\section{A képregényről röviden}

A képregények használata az oktatásban egyáltalán nem új keletü: a legtöbb nyelvkönyvben találhatunk egy-egy comic stripet vagy karikatúrát. Ezeknek azonban többnyire „helykitöltő” jellege van, sokszor nem is kapcsolódik a rajzhoz feladat vagy magyarázat. De az, hogy képekkel könnyebb a tanulás, senki nem vitathatja. Ezért van az többek között, hogy ha belelapozunk egy nyelvkönyvbe, rengeteg színes fotót, rajzot és illusztrációt láthatunk. A számtalan képes szótár is ezt a felfogást erősíti. A Hachette francia kiadó 1971-ben jelentette meg „Le Français et la vie” címü nyelvkönyvét, ahol a baloldalon csak rajzokat, képtörténeteket látunk, a jobboldalon pedig a képekhez tartozó dialógust. A könyv érdekessége, hogy a legtöbb rajzos tankönyvvel ellentétben ez a könyv a felnőtteknek szól elsősorban. Az angol Hutchinson 1995-ben adta ki „Project” címü angol nyelvkönyvét gyerekeknek. A könyv immáron 22 kiadást ért meg és a rengeteg rajz mellett szinte minden leckében találunk egyoldalas képregényeket. A németek első, nemzetközileg is elterjedt nyelvkönyve a „Themen” szintén tartalmaz egy-egy képregényt, kifejezetten nyelvtani gyakorlatokhoz kapcsolódó feladatokkal.

A képregény története külön dolgozat témája lehetne, ezért most - a teljesség igénye nélkül csak néhány meghatározó momentumot emeljünk ki a rajzos képtörténetek múltjából. A képregény megítélése az elmúlt évtizedekben sokat változott. Nálunk Magyarországon elég mostohán bántak vele, így ha a magyar képregény kultúráról kellene írnom, akkor nem sok pozitívumot tudnék megemlíteni. Szerencsére lassan itthon is helyén kezelik a müfajt, hiszen egyre több képregényes rendezvényt szerveznek és a látogatók száma is folyamatosan nő. Azonban vélhetően még pár évnek, évtizednek el kell telnie, hogy úgy viszonyuljunk a képregényekhez, mint például az Belgiumban tapasztalható, ahol számos képregénybolt mellett Európa első képregény múzeuma is található. Sőt: a belga fövárosban szinte minden utcasarkon találkozhatunk képregény-figurákkal, hol szobor, hol tüzfal-grafika formájában. A képregényt ott és Nyugat-Európában a „kilencedik müvészetnek” tartják, a rajzolókat pedig megbecsülés övezi. Ehhez képest 1993-ban, amikor az egyetemen a tanárnő azt kérte, hogy mondjunk irodalmi müfajokat, felvetettem a képregényt, az egyetemi oktató kijelentette: az nem irodalom. A képregénynek ilyen szélsőséges megítélése talán már csak a múlté... Legalábbis reménykedjünk... 
Azt, hogy a képregény megjelenését honnan számíthatjuk, meglehetősen nehéz eldönteni (Gellért, 1975; McLoud, 2007, 2008; Rubovszky, 1988, 1989; Szalay, 2003). Ha nagyon akarnánk, akkor egészen a barlangrajzokra is visszavezethetnénk a müfajt, hiszen ott jelennek meg először képekben ábrázolt események (például a vadászat megjelenítése). Időszámításunk előtt 1300-ból származik az az egyiptomi tekercs egy halottas könyvböl, amely rajzokkal mutatja be, hogy mi történik a lélekkel a halál után (Osala La Mort).

Európában az első képregényhez köthető müvet a svájci Rodolphe Töpffer alkotta 1827-ben „Amours de Monsieur Vieux-Bois” címen. Nemsokkal később, 1865-ben jelent meg Németországban a „Max és Moritz” Wilhelm Buschtól, ami az első német verses képtörténetnek tekinthető (Gellért, 1975). Német nyelvterületen a képregények hamarosan az írás-olvasás- és irodalomtanításban is felhasználásra kerültek (Hoffmann és Rauch, 1975).

Magyarországon a 19. század második felében jelentek meg először a rajzos képsorozatok, melyek hasonlítanak Wilhelm Busch képsoraira. A rajzokat Jankó János, míg a szöveget sokan most biztosan meglepődnek - Jókai Mór készítette, aki korábban saját maga is rajzolt az általa szerkesztett élclapokba: a Nagy Tükörbe (1856-1958) és az Üstökösbe (1858-1910).

Itt célszerü szót ejteni a comic strip-ről, a képregény egyik almüfajáról. A comic strip esetében a csattanóig mindössze néhány képkockát kell csak elolvasni, hiszen 3-4 kockából álló „komikus csíkról” van szó, mint ahogy arra a neve is utal. Érdekesség, hogy a képregény (comics) és a comic strip angol nevében ugyan benne van a „vicces”, „komikus” szó, ám a mai képregények egy része egyáltalán nem hủ a nevéhez, hiszen nyomokban sem tartalmaz humort. A comic stripek elsőként a 19. század végén észak-amerikai napilapokban jelentek meg, de mind máig a napilapok közkedvelt részei. A tengerentúlon a legtöbb napilap a hétvégi mellékletében egy teljes oldalt szentel a képcsíkoknak.

A comic strip tehát egy tipikusan az amerikai sajtóra jellemző grafikai alkotás (Rubovszky, 1988, 1989). Hazánkban Mühlbeck Károly próbálkozott meg a müfaj egy teljesen új értelmezésével és hétről hétre „fejlécek” formájában adott hírt egy-egy történésről. Bár a fejlécek formailag hasonlítottak az amerikai elődre, de mégsem nevezhetjük ezeket comic stripnek. Mühlbeck fejlécei szalagszerü, hosszúkés rajzok voltak, de a sokszor több jelenetet felvonultató csíkokon nem különültek el az egyes rajzok egymástól és a rajzot egészében kellett szemlélni, a csattanó tehát nem az utolsó képkockába került, hanem a szalag-rajz és az alatta olvasható szöveg teljes tartalmi egységet alkotott.

Következzék most néhány javaslat a comic strip-ek és a képregények (nyelv)oktatás célú alkalmazásához - nemcsak különleges bánásmódot igénylő tanulók számára:

1. A párkereső játék comic strip-ekkel. Kiválasztunk 3-4 képregény-csíkot, amit kockákra vágunk. A csoportlétszámnak megfelelően úgy kalkuláljunk, hogy minden tanulónak jusson egy darab rajzocska. Az órán körbejárunk egy kalappal, amiből, minden tanuló kihúz egy képkockát. Ezután kezdődik a feladat: a tanár tapssal jelzi a játék kezdetét: a tanulók pedig nekiindulnak és megpróbálják megtalálni a kezében lévő rajzuk folytatását, avagy bevezetését. Ha két tanuló „egymásra talál”, összeillesztik a rajzaikat és ezután kettesben folytatják a keresést, egészen addig, míg a comic strip teljessé nem válik. Ha megvannak a kész csíkok, jöhet egy utolsó kör: a csoportok megmutatják egymásnak a kész csíkokat. Hogy még izgalmasabb legyen a játék, választhatunk olyan comic stripeket, amelyek kronológiai sorrendbe rakhatók és van szoros tartalmi-kohéziós szál az egyes csíkok között. Így a végső játék a csoportok között a helyes sorrend felállításáról szól majd - ez a szerialitás, az oksági gondolkodás és az időrend szerint szerkesztett szövegek átszerkesztését (Mező, 2011) is segíti. Érdekes történetek jöhetnek ki akkor, ha megpróbálunk úgy értelmet keresni a történetnek, ha a három kocka nem az eredeti sorrendben van. Matematikailag a három képkockával hat különböző sorrendet lehet felállítani, azaz hat különböző történetet is kreálhatunk három képkocka segítségével. 
2. Kreatív történetalkotás comic strip alkalmazásával. A tanár kiválaszt egy három kockából álló comic strip-et, a rövid történet középső darabját pedig kinagyítja és felragasztja a táblára. A diákoknak azt kell együtt kitalálniuk, hogy vajon mi lehet az első, illetve utolsó képkockán.

3. Történetmesélés. Az egyik diák kiáll az osztály elé, megkapja az egyoldalas képtörténetet (lásd: 5. ábra), amit idegen nyelven mond el, a többiek pedig a végén megpróbálják visszamondani, amit értettek. A mesélés közben mindenki leírja a megszerzett információkat, majd a történet végén eláruljuk, hány kockából áll a történet, így a diákok megrajzolhatják a saját verziójukat is. Miután az ellenőrzés megtörtént, házi feladatnak készíthetünk egy kis szöveges összefoglalót a történetröl, amelyböl kihagyunk szavakat. Ezeket a szavakat kell a diákoknak behelyettesíteniük.

5. ábra: példa a történetmesélést provokáló képregényekkel kapcsolatban. Forrás: Szalay (2014, 112. o.) Deutsch mit Comics 2. címü müvéböl

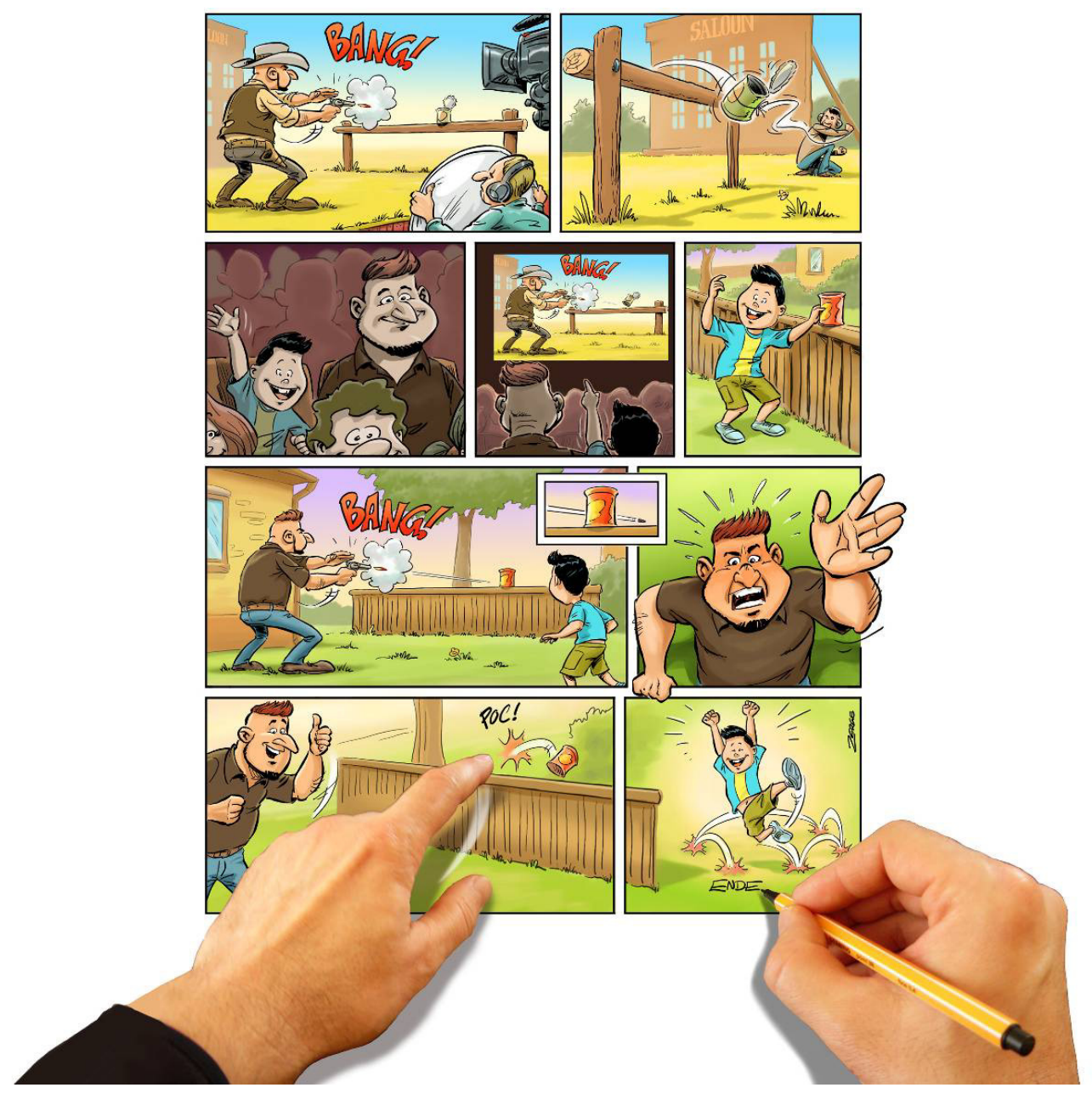

4. Történet továbbgondolás. A történetmesélés feladatot lehet még tovább variálni: amikor már az eseménysor adott, kérjük meg a gyerekeket, hogy illesszenek a történetbe más történetekből vett szereplőket és fogalmazzák át velük a történetet. 
5. Történet befejezés. A tanár kiosztja a diákoknak a történet első három sorát és közösen megbeszélik a látottakat. Ezután következik egy kis csoportmunka: a diákok kettes-hármas csoportokban megírják a történet általuk elképzelt humoros folytatását illetve a csattanót, amit egyikük meg is rajzolhat. A variációkat együtt megvitatjuk, majd megnézzük az eredeti történet végét. Az alternatívák keresése nagyon jó, kreativitást igénylő gyakorlat. Amikor már azt hisszük, nincs több lehetőség, akkor kiderül, hogy nem egy, hanem még végtelen számú variáció merülhet fel egy történet végkifejleténél is. Ez elsősorban a fluenciát, a gondolatok és ötletek folyékonyságát, valamint az elaborációt erősíti, a határokat kitágítja, s nyitva hagyja a lehetőséget újabb és újabb alternatívákra. A diák a képzeletét, fantáziáját használja, ami az eredeti gondolkodást segíti. Hiszen - Einstein gondolatát idézve - a képzelet több, mint a tudás, mert a tudás véges, de a képzelet végtelen (Net1). A történet befejezős feladatra adott reakciók: a diákok ugyan meglepődnek a szokatlan feladaton, de utána görcsmentesen és gátlások nélkül beszélgetnek más témákról is.

6. Történetmesélés nézőpontváltással. A történetmesélős feladatoknál alkalmazhatunk egy másik kreativitást fejlesztő technikát: a nézőpontváltást. Az adott történetet a diákok egy másik szereplő vagy akár egy, a történetben is résztvevő tárgy szemszögéből mesélik el.

7. Sorba rendezés. A már comic strip-nél kipróbált kockákra vagdosás itt az egyoldalas képregénynél még nagyobb kihívás és nagyon kedvelt móka. Párokban vagy egyénileg a legideálisabb, a csoport létszámától függően. Feladat: a felvagdalt, összekeveredett képkockák sorba rendezése (6. ábra). Az ilyen típusú feladatok a szerialitás képességének gyakorlását, illetve a tanulás Mező-féle IPOO-modelljében megjelenő ,aátszerkesztést” gyakoroltatják időrend szerinti logikai szerkezettel bíró szövegek, képsorozatok esetében (Mező, 2011).

6. ábra: példa egy időrendi sorba rendezési feladatra alkalmas képregényre. Forrás: Szalay (2014, 119. o.) Deutsch mit Comics 2. címü müve

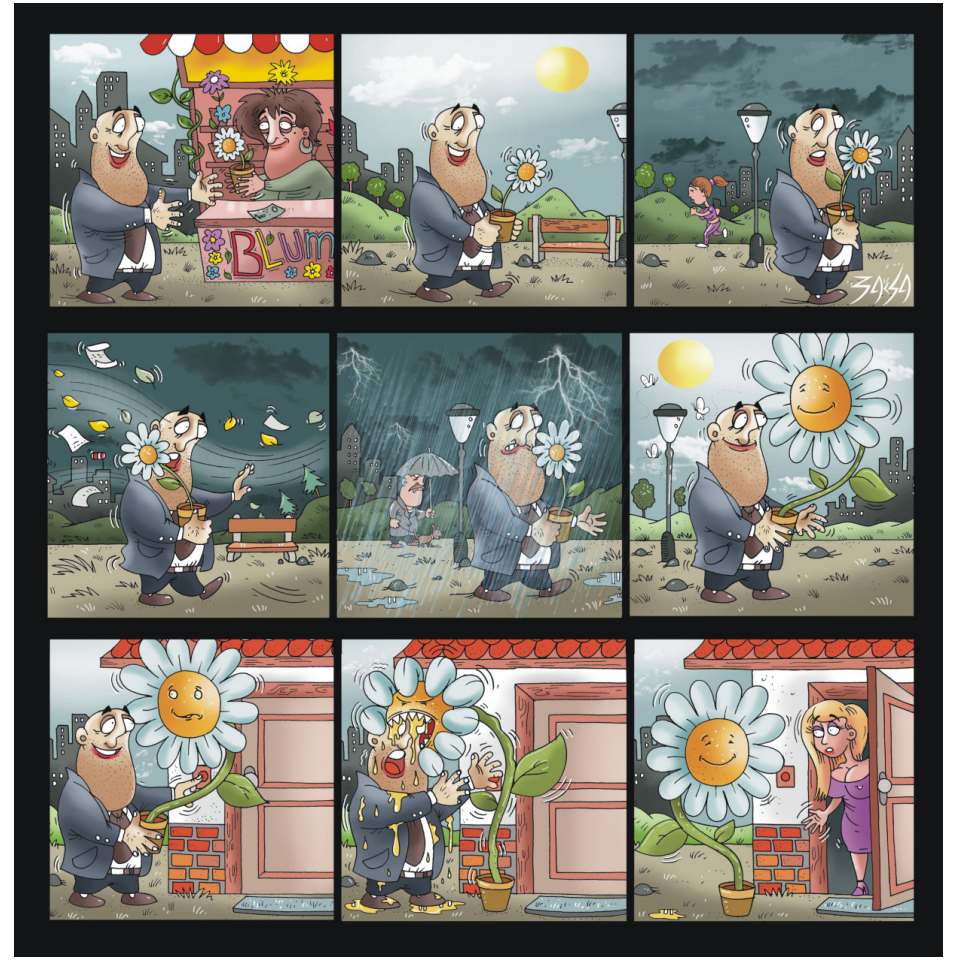


Megjegyzendő, hogy az IPOO-modellben (Mező, 2011) leírt bemutatás, összehasonlítás és fogalmi hierarchia jellegü információszerkezetek felismerése, értékelése (jól/rosszul van-e szerkesztve az információhalmaz) és adott esetben átszerkesztése is hasonló módon gyakoroltathatók képregények segítségével.

8. Képrege színház. A szöveges képregényt a diákok eljátszhatják, ezzel begyakorolják a szöveg szavait és kifejezéseit.

9. Buborék-írás. Szöveges képregények esetén kitöröljük a szöveget a buborékokból és a gyerekek megpróbálják a képek alapján kitalálni, ki mit mondhat az adott helyzetekben (7. ábra). Ezt a feladatot iskolai nyelvi pályázat keretében is végezhetjük.

7. ábra: buborék írás. Forrás: Szalay (2014, 2. o.) Deutsch mit Comics 2. címü müve
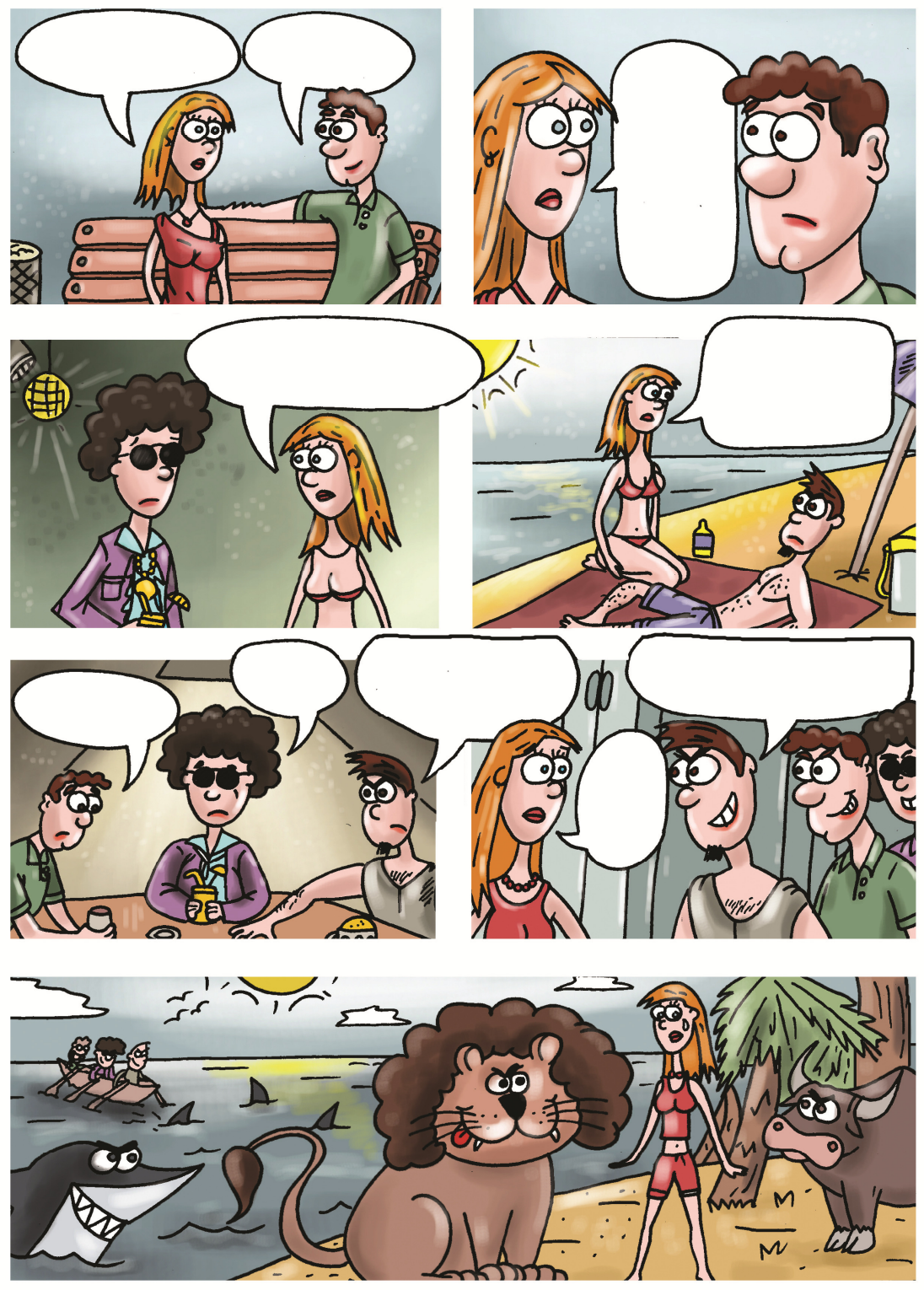
10. Saját képregény alkotása. Kiosztunk egy sablont a gyerekeknek: a sablonon üres képregény-kockák és szöveg nélküli buborékok vannak rajta. Mindenki - egyénileg vagy csoportosan - saját képregényt rajzol. Ezt a feladatot iskolai vagy kerületi verseny szintjén igazán nagyszerü végezni.

11. Viccekhez, közmondásokhoz képregények, comic strip-ek alkotása. Készítsenek a diákok egy kiválasztott vicchez/közmondáshoz rajzot. A többiek kitalálják, melyik vicchez/közmondáshoz készült a rajz. A kiválasztott vicc/közmondás megtanulását követően azt a csoport előtt is elö lehet adni.

12. Összetett gyakorlat képregény, film és zene összekapcsolásával. Végezetül következzék egy, jelen tanulmány szerzője által kifejlesztett olyan gyakorlat, amely összekapcsolja az eddig bemutatott eszközöket egy másik médiummal, a filmmel, illetve a filmhez szervesen hozzátartozó filmzenével! A diákok két-három fös csoportokba rendeződnek. Minden csoport egy kétoldalas, szövegnélküli manga-képregényt kap. Az első feladat: együtt megbeszélni és értelmezni a képeket és a képsorozat jeleneteiből megfejteni az összefüggő történetet, amely nem is mindig bizonyul olyan könnyünek, mint azt az ember elsőre gondolná.

\begin{abstract}
Az egyik középiskolás, egyetemista, felnőtt korosztálynak szóló konkrét mangának a története például egy pesti villamoson kezdődik: egy fiú és egy lány ül egymással szemben, szemeznek, majd a fiú hirtelen leszáll, de az esernyője a villamoson marad. A lány az esernyőben talál egy cédulát, amiből megtudhatjuk: ez a fiú kedvenc esernyője és a becsületes megtalálónak pénzjutalmat ajánl. A lány elviszi az esernyőt a cetlin feltűntetett címre. A fiú nem győz hálálkodni és beinvitálja a lányt, akinek vacsorát készít. A fiú zongorázik a lánynak, majd táncolnak és egy esernyős fotó is készül a lányról. Másnap reggel a lány a fiú ágyában ébred - amikor a ruháit keresi, az ágy alatt rengeteg ,kedvenc esernyőt" talál és egy fotóalbumot a becserkészett lányok képeivel. A srác tehát nem más, mint egy mániákus gyüjtő: lányokat gyüjt egy éjszakára esernyők segítségével. A fiú még alszik, így a csalódott lány észrevétlenül távozik az ágy alatt talált esernyőkkel. Bosszúja azonban nem marad el: az ágy alatt talált esernyőket kigyúrt és marcona férfiak között osztja szét, akik egymás után jelentkeznek a fiúnál és behajtják rajta a cédulán említett megtalálói jutalmat. Eddig a történet, amelynek egyes elemei azért nem teljesen egyértelműen következtethetők ki a képregény kockáiból, de a lényeget általában sikerül a diákoknak megfejteni.
\end{abstract}

A gyakorlat második részében a párok megkapják a történet szövegét németül és 12 részre vagdosva. A sorrend felállítása és megbeszélése után pedig egy szokatlan feladat következik: a tanár öt darab zenei részletet játszik le a tanulóknak, akiknek asszociálniuk kell, melyik zeneszám a történet mely jelenetéhez passzolna leginkább, ha nem képregényről, hanem filmről lenne szó. Végül lehull a lepel: a tanár levetíti azt az ötperces rövidfilmet, melynek címe „A kedvenc esernyő” és amely alapján a manga készült.

További karikatúrákon, képregényeken alapuló feladattípusok találhatók még Mező és Mező (2014) müvében.

\title{
Összefoglalás
}

Az elmúlt években felcseperedett egy teljesen új generáció, amelyet egészen más hatások és ingerek értek az óvodás, iskolás évek alatt - ezekre a megváltozott igényekre próbál alternatívát nyújtani a képregények, karikatúrák révén történő oktatás, s az ezt szolgáló nyelvkönyv (Szalay, 2013, 2014), ami a más tankönyvekhez képest teljesen szokatlan és újszerü formával és tartalommal közelít a nyelvtanuláshoz. A tankönyvek száraz tényeit 
humorral is lehet vonzóvá tenni, ha hagyjuk, hogy a tanulók kilépjenek az iskolai keretekből és engedjük kreativitásukat, ötleteiket szabadon szárnyalni a tanagyag könnyebb befogadása érdekében.

Ahogy azt Gyarmathy (2011) is írja, egy olyan digitális korban élünk, ahol hatalmas az információáradat, a gyereket rengeteg inger veszi körül, de egyre kevesebb a verbális nyelvi inger, helyette viszont annál több az auditív és vizuális inger. A gyerekek feje a szövegek helyett hangokkal és képekkel telítődik. A szövegekben rejlő információkat a képek közvetítik, a gyermek pedig ezek alapján alakítja ki saját képét a világról. Kérdés persze, hogy tud-e egyáltalán rendet tenni a kis fejében, ahol kész információ-káosz uralkodik.

A feladat tehát adott: rendszert kell vinni ebbe a káoszba és segíteni a gyereknek, hogy rendezni tudja ezeket az ingereket - ennek a rendszernek a kiépítése a Mezö-féle IPOOmodellre (Mező, 2011) épülő, a képregényeket, karikatúrákat is alkalmazó tanulás módszertannal lehetséges.

\section{Irodalom}

Gellért E. (1975). A képregény története. Tömegkommunikációs Kutatóközpont, Budapest.

Gyarmathy É. (2011). Kreativitás és beilleszkedési zavarok. In Münnich Á. (szerk.). A kreativitás többszempontú vizssálata. Didakt Kiadó, Debrecen. 9-40.

Gyöngy K. (2008). Magyar karikaturisták adat- és szignótára 1948-2007. Magánkiadás.

Hoffmann, D. és Rauch, S. (1975). Comics - Texte und Materialien zum Literaturunterricht. Berlin: Verlag Moritz Diesterweg.

Kaposy M. (2001). Humorlexikon. Tarsoly Kiadó, Budapest.

Koczogh Á. (1981). Vázlat a karikatúráról. Tudományos Ismeretterjesztő Társaság, Budapest. McLoud, S. (2008). A képregény mestersége. Nyitott könyvmühely, Budapest.

McLoud, S. (2007). A képregény felfedezése. Nyitott könyvmühely, Budapest.

Mező F. (2011). Tanulás: diagnosztika és fejlesztés az IPOO-modell alapján. K+F Stúdió Kft., Debrecen.

Mező F. és Mező K. (2014). A Nemzeti Tehetség Program népszerüsítésének lehetőségei. Kocka Kör, Debrecen.

Net1: Albert Einstein. Letöltés: 2013.4.07., Web: https://hu.wikiquote.org/wiki/Albert_ Einstein

Osala La Mort. Letöltve: 2013.04.04. Web: http://osara.wicca.hu/halott.html

Rubovszky K. (1988). Apropó, comics! Müvelődéskutató Intézet, Budapest.

Rubovszky K. (szerk.)(1989). A képregény. Gondolat Kiadó, Budapest.

Szalay K. (2003). Karikatúra és groteszk a magyar középkorban. Mundus, Budapest.

Szalay K. (2013). Deutsch mit Comics 1. Central Holding Magyarország Kft, Budapest.

Szalay K. (2014). Deutsch mit Comics 2. Kocka Kör Tehetséggondozó Kultúrális Egyesület, Debrecen. 